Research Article

\title{
Mechanical Interpretation of Effects of Aeolian Fine Sands on Coal Fly Ash in Northern Shaanxi Province, China
}

\author{
Xin Wei $\mathbb{D}^{1},{ }^{1}$ Chongyang Gao $\mathbb{D}^{1},{ }^{1}$ Keyu Ai, ${ }^{2}$ Jun $\mathrm{Zhao}^{3}$ and Ling Xu ${ }^{1}$ \\ ${ }^{1}$ Department of Civil Engineering, School of Human Settlements and Civil Engineering, Xi'an Jiaotong University, Xi'an 710049, \\ China \\ ${ }^{2}$ Management School, The University of Sheffield, Sheffield S10 2TN, UK \\ ${ }^{3}$ Department of Design, China United Northwest Institute for Engineering Design \& Research, Xi'an 710077, China
}

Correspondence should be addressed to Chongyang Gao; gaochongyang2387@163.com

Received 7 September 2020; Revised 29 October 2020; Accepted 29 October 2020; Published 12 November 2020

Academic Editor: Jian Xu

Copyright (c) 2020 Xin Wei et al. This is an open access article distributed under the Creative Commons Attribution License, which permits unrestricted use, distribution, and reproduction in any medium, provided the original work is properly cited.

\begin{abstract}
The coal fly ash (CFA) is massively produced as a consequence of coal source residues in Northern Shaanxi Province, China. Since disposing the waste materials in mountainous gully widely distributed in the same area is one of the possibilities, the high compressibility and low strength of CFA become a severe problem for the stacking. The aeolian fine sands are close to Mu Us Desert, as the addition material was introduced to improve the mechanical behaviours of CFA. A series of oedometer and triaxial tests were performed on pure CFA, pure sands, and their mixtures containing $25 \%, 50 \%$, and $80 \%$ of sands by weight, respectively. Test results were analyzed within the framework of critical state soil mechanics. With increasing sands content, normally consolidated lines (NCLs) and critical state lines (CSLs) of tested materials change in volume space as well as their compression or shearing paths. The mechanical parameters like $C_{c}, \Gamma, \lambda$ decrease as a result of increasing sands content. On the contrary, the $M$ and $\varnothing_{c s}$ increase with augmenting sands content. It is concluded that the aeolian sands can significantly decrease the compressibility of the CFA and increase its shear strength. These findings would be useful for the treatment of CFA, which is significant for solving environmental problems in northern Shaanxi Province.
\end{abstract}

\section{Introduction}

$\mathrm{Mu}$ Us Desert, located on the northern edge of the Chinese Loess Plateau, is one of the most important energy industry bases in China. A huge amount of mining residues is produced, e.g., the coal fly ash (CFA) is up to about $1 \times 10^{10} \mathrm{~kg}$ in 2020 [1] (see Figure 1). The CFA might have some heavy metals, such as copper, zinc, chromium, cadmium, and lead. It will give rise to serious geoenvironmental problems if the CFA cannot be disposed properly. The aeolian fine sands are widely distributed in northern Shaanxi Province, which is very close to $\mathrm{Mu}$ Us Desert. These sands are very weak in water-holding, and not suitable for agriculture [2-8]. The CFA is composed of some strong waterabsorption materials. Because of the complementary waterholding characteristics of CFA and aeolian fine sand, the large amount of CFA can be taken as a potential solution to improve the water-holding capacity of sands. Since the gullies are the typical morphology in northern Shaanxi Province, landfill might be a possibility to dispose such huge amount of CFA. Filling gullies using the mixtures of aeolian sands and CFA might take advantage of both materials.

The pure CFA is with high compressibility and low strength. Due to the relatively small particle size and highwater content, such geomaterials often have a high risk of failure due to liquefaction, causing catastrophic landslides and debris flows [9-18]. The effects of CFA, as an addition to treat soils, have been analyzed by some researchers. Nilo et al. [19] and Consoli et al. [20-22] studied the behaviour of compacted soil-fly, ash-lime mixtures, and variables governing soil strength. Bedin et al. [14] and Carrera et al. [23] successfully investigated the behaviour of gold or Stava tailings within the critical state framework. Under this framework, the effects of finer particles, i.e., silts on sands 


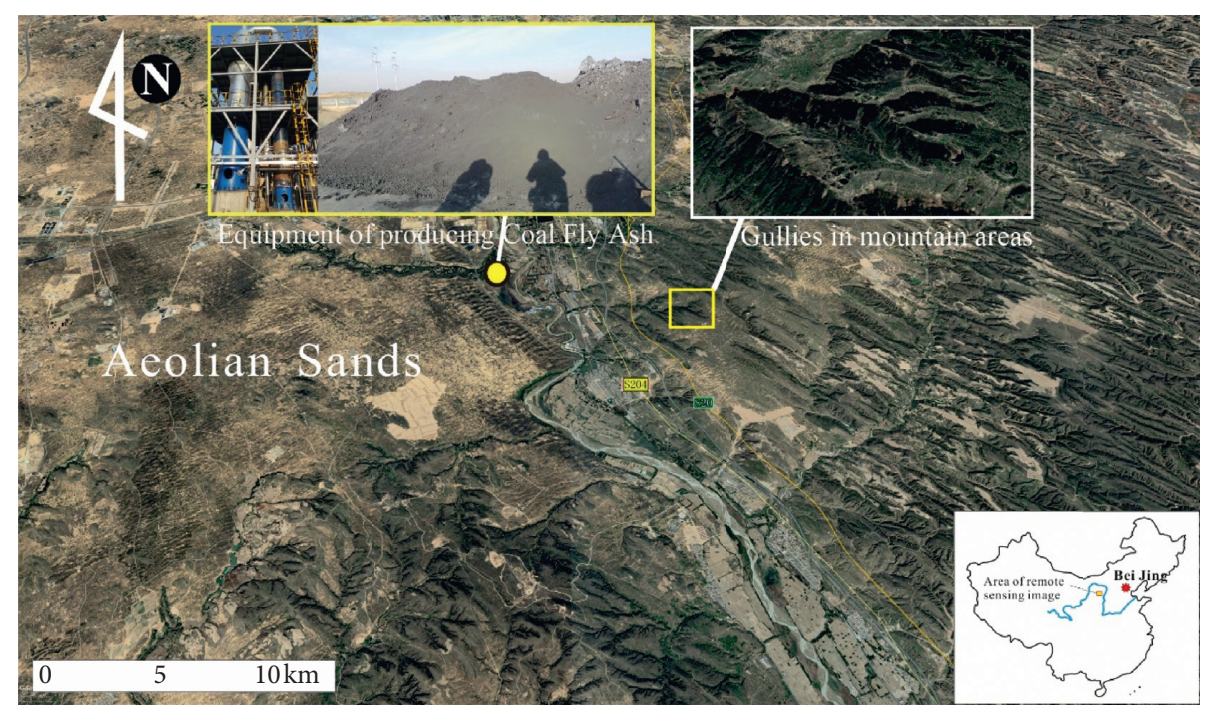

FIgure 1: Distribution of coal fly ash in northern Shaanxi Province, China.

behaviour, have been analyzed [24-27]. It can be seen that the fly ash is normally employed as additive and to be mixed with soils with poor geotechnical characteristics for the purpose of improving their mechanical properties. The activators like cement or lime are also added for the purpose of triggering the required chemical reactions to make the treatment more effective.

Aeolian sands are distributed in sandy areas, principally in desert areas [28]. They are nonplastic and uniformly sized materials with particles of fine to medium. Because of the different sedimentary environment, the physical, morphological, chemical, and mineralogical properties of aeolian sands vary in different areas. Their characteristics even vary at different depths at the same area [29-33]. In the research of Howari et al. [34], the geomorphology and mineralogy of different dune types in the United Arab Emirates were analyzed combined with field and image processing techniques. They found that the dunes can be divided into two types on the basis of composition and morphology. Aeolian sands are considered to be the main construction materials in sandy areas. However, due to the poor grading, great uniformity, and nearly zero cohesion, their mechanical properties need to be improved [32, 35-37]. The attempts for improving the mechanical characteristics of aeolian sands have been carried out for many years through the application of reinforcement materials.

Different cementing agents are frequently used for improving the stabilization of aeolian sands, for example, Portland cement, calcium carbonate, and bitumen. Test results showed that the addition of cementing agent to aeolian sands with uniform size distribution can greatly improve the mechanical behaviour of aeolian sands due to cementation or cohesion fabricated by particle frictions $[33,38,39]$. Except the above agent materials, the application with slag residues materials, solid waste ashes, or ceramics wastes is more and more frequently. In addition to the low cost, the advantages of using these waste materials include avoiding the storage or disposal, which generally are not friendly to the environment. The experiments on the application of municipal waste ashes were carried out by Mohamedzein et al. [40]. It is found that the unconfined compressive strength and shear strength of aeolian sands are considerably ameliorated. Ameta et al. [41] did researches on ceramic tiles wastes, which greatly stabilize the dune sand. A waste product generated during the manufacture of Portland cement was also evaluated for the reinforcement of dune sands. The results showed that the addition of these wastes changes the compaction curves of aeolian sands [42]. Albusoda and Salem [43] confirmed that when the sands were mixed with Cement kiln dust, the liquid limit decreases, and the strength parameter increases, which lead to an ultimate increasing bearing capacity. These recent researches identify that the additions of agents are necessary for improving the unconfined compressive strength or hydraulic conductivity of aeolian sands.

It can be seen from the literatures that the most frequently used agent materials are cement and lime, which have the advantages of ameliorating the strength and stiffness of aeolian sands. However, these methods need high extra costs and usually large amount of water, which is a precious resource in semiarid or arid areas. Bitumen is also frequently used as the addition material for aeolian sands. The costs are relatively lower than those of the other agents. In another aspect, bitumen agents alone produce weak cementing. Therefore, the addition of cement or lime is still needed for increasing the strength and decreasing curing times. In the last years, more alternative materials, which are more sustainable and environmentally friendly, have been considered for improving the mechanical properties of aeolian sands for the purpose of engineering construction. Thus, the mixtures of CFA and aeolian sands can be considered to be a novel solution for both improving the mechanical properties of CFA and the stabilization of aeolian sands. In addition, the consumptions of CFA with aeolian sands are a good option since they do not require storage and disposal of residues. 
The principal aim of this research is to investigate the mechanical properties of pure CFA and its mixtures with aeolian sands by employing the aeolian sands as additive for the purpose of improving the mechanical behaviour of pure CFA. Therefore, a low-cost and easily operated method to dispose CFA is discussed. With this purpose, a series of oedometer and triaxial tests were, therefore, performed on pure CFA, pure sands, and their mixtures containing $25 \%$, $50 \%$, and $80 \%$ of sands by weight, respectively. The testing data was analyzed within the critical soil mechanics framework.

\section{Materials and Methods}

The CFA was collected from flue gas produced in northern Shaanxi Province, China. Compared with the aeolian fine sands, the particle size of CFA is much smaller. Figure 2 reveals that the percentage of particles with the size less than $0.3 \mu \mathrm{m}$ is up to about $90 \%$. It is obvious that the CFA is dominated by spherical particles (see Figure 3(a)). Some smaller spherical particles or needle-like crystals are attached to the surface of the big spherical particles, and some spherical particles also conglutinate together. Based on slice identification and $X$-ray diffraction, it is identified that the main minerals of CFA are Mullite, feldspar, and quartz.

The aeolian fine sands used in this study were collected from the $\mathrm{Mu}$ Us desert. The particle size distribution of the tested aeolian fine sands is shown in Figure 2. The content of sands $(2-75 \mu \mathrm{m})$ is up to about $90 \%$. From SEM observations, the aeolian fine sands are featured for the irregular shape of particles (see Figure 3(b)), which is different from that of water-formed sands [44]. The dry density of the aeolian fine sands is about $1.26-1.71 \mathrm{~g} / \mathrm{cm}^{3}$ with a specific gravity of 2.64. Mineralogical analysis shows that the predominant mineral is quartz, with less contents of amphibole, epidote, and garnet. The particles of aeolian sands are frequently finer than the general sands such as river sands or sea sands so that the wind can transfer them to the other areas. The aeolian sands are with more edges and corners and more irregular shapes than the other types of sands.

Oedometer and triaxial tests were performed on reconstituted samples. Tables 1 and 2 show details of oedometer and triaxial tests, respectively. The aeolian fine sands, CFA, and distilled water were weighed firstly; then they were mixed together with different proportions until the mixture was homogeneous [45]. The soil samples were sealed for about $24 \mathrm{~h}$ before tested in order to avoid the air bubbles. The triaxial samples were with the diameter of $50 \mathrm{~mm}$ and the length of $100 \mathrm{~mm}$. The diameter and the height of the oedometer samples were $50 \mathrm{~mm}$ and $20 \mathrm{~mm}$, respectively. The tested samples were compacted in four layers into the testing mold for the purpose of reaching a consistency state with a target initial void ratio and a water content of about $20 \%$. After the molding process, the specimen was weighed, and the diameter and height were measured with the accuracies of about $0.01 \mathrm{~g}$ and $0.1 \mathrm{~mm}$, respectively.

The accuracy of the initial specific volumes $v(=1+e)$ was calculated using two methods. With the first method, the initial dimensions and weights of the samples are measured, while the second method combines the water contents measured at the end of the tests with the volumetric strains measured during testing. An average value of $v$ is reported in Tables 1 and 2. The estimated error of the initial specific volume is about $1-2 \%$ for the aeolian fine sands, CFA, and their mixtures. Samples are considered fully saturated if $B$ values are above 0.98 . During saturation process of triaxial tests, the samples were firstly flushed by deaired water at a very low effective stress to avoid potential disturbing on the samples. Then, the back pressure of $500 \mathrm{kPa}$ with a small stepped increase was used to saturate the samples. The slow saturation process demanded an adoption period of 24 hours for the samples.

\section{Results and Discussion}

3.1. Compressive Characteristics. The oedometer data for CFA, pure sands, and their mixtures are presented in Figure 4(a). The compression paths of CFA are highest among all the materials in $v$ - $\ln \sigma_{v}^{\prime}$ plane. With the influence of sands, the compression paths for CFA shift downwards and become stiffer even at the end of the tests. The NCLs for the CFA and CFAsands mixtures have been identified. With the increasing content of sands, the NCLs shift downwards and spin anticlockwise. It is worth noting that the compression paths of $80 \%$ sands overlapped with those of pure sands. Their detailed curves are demonstrated in Figure 4(b). The mixture of $80 \%$ sands is more compressible than that of pure sands though their compression paths overlapped. The result of compression index $\left(C_{c}\right)$ versus the sands contents in mixtures is shown in Figure 5. The $C_{c}$ value of pure sands is replaced by $80 \%$ sands because it does not reach its real NCL. It reveals that the $C_{c}$ deceases with increasing sands content. With the increase of sands content, as shown in Table 1, the initial void ratio of the mixtures gradually decreases, which decreases the plasticity of the mixtures. Thus, the compressibility of the mixtures decreases. It is concluded that the sands have effect on the compressive characteristics of the tested materials.

3.2. Stress-Strain Results. The stress-strain results for the tested materials during drained and undrained triaxial tests are shown in Figures 6 and 7, respectively. To eliminate the effects of the effective confining pressure $p_{0}^{\prime}$, the shear stress and pore pressure variations are normalized by initial effective confining pression $p_{0}^{\prime}$. Most of the tests were terminated at axial strains of $30 \%$ at least when they had generally reached constant stress and volume states.

In drained tests, the CFA, 25\% sands and 50\% sands exhibit a similar mechanical behaviour. They experienced an initially small shear stiffness and then reached final values, which are close to those of $80 \%$ sands and pure sands (see Figure 6(a)). In volume strain results, the CFA, $25 \%$ sands, and $50 \%$ sands all show a contractive tendency (see Figure 6(b)). The $80 \%$ sands and pure sands present higher initial stiffness, and they are both dilative in volume strain. Similar results are also obtained in undrained tests (see Figure 7(a)). For pure CFA, 25\% sands, and $50 \%$ sands, their behaviours are contractive. On the 


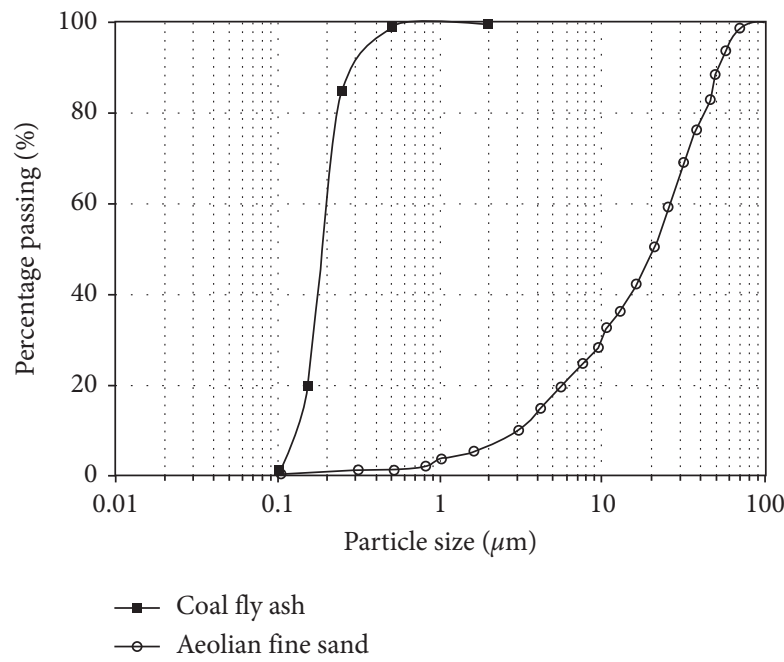

Figure 2: Particle size distribution of coal fly ash (CFA) and aeolian fine sand used in this research.

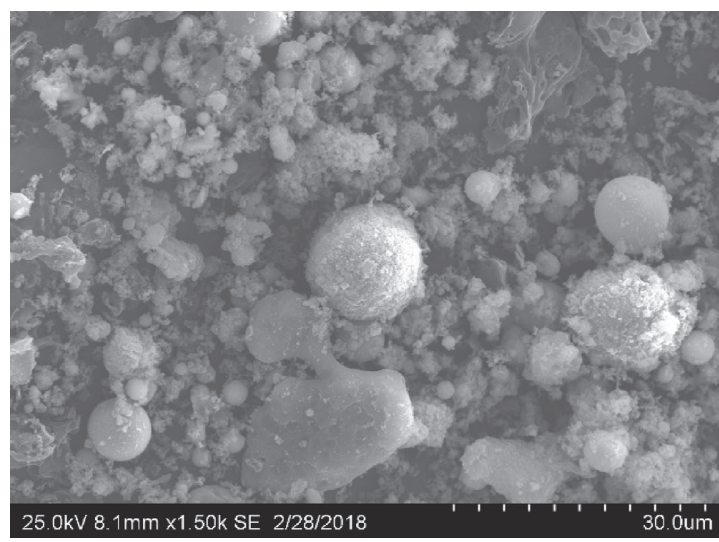

(a)

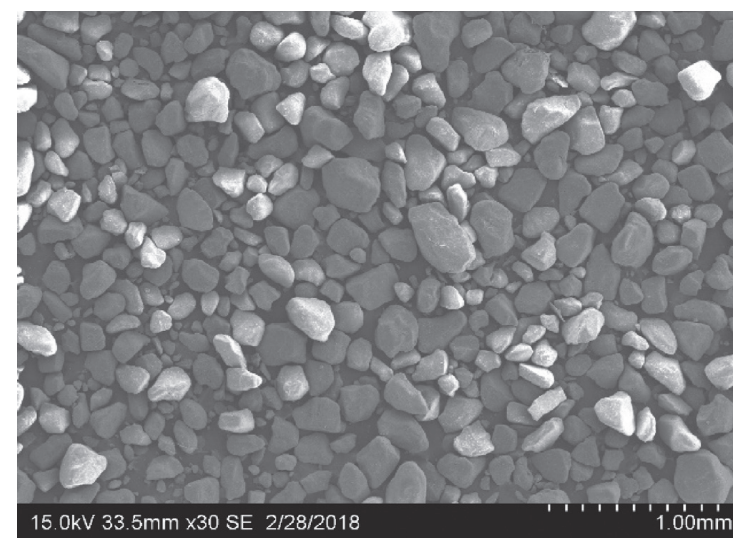

(b)

Figure 3: SEM images of (a) coal fly ash (CFA) with magnification of 1500 and (b) aeolian fine sands with magnification of 30.

TABLE 1: Details of the oedometer tests.

\begin{tabular}{lcccc}
\hline Test name & $G_{s}$ & Initial specific volume: $v_{0}$ & Maximum vertical pressure: $\sigma_{v \max }^{\prime}(\mathrm{MPa})$ & Final specific volume: $v_{f}$ \\
\hline CFA & \multirow{2}{*}{2.780} & 4.218 & 4.3 & 2.641 \\
CFA & 3.910 & 4.3 & 2.641 \\
\hline $25 \%$ sands & \multirow{2}{*}{2.745} & 3.423 & 4.9 & 2.103 \\
$25 \%$ sands & & 3.078 & 4.9 & 2.103 \\
\hline $50 \%$ sands & \multirow{2}{*}{2.700} & 3.308 & 5.3 & 1.897 \\
$50 \%$ sands & & 2.718 & 5.3 & 1.897 \\
\hline $80 \%$ sands & \multirow{2}{*}{2.665} & 1.804 & 5.1 & 1.580 \\
$80 \%$ sands & 1.620 & 5.1 & 1.499 \\
$80 \%$ sands & & 1.592 & 5.1 & 1.483 \\
\hline Sands & & 1.626 & 5.3 & 1.552 \\
Sands & \multirow{2}{*}{2.640} & 1.615 & 5.3 & 1.543 \\
Sands & & 1.608 & 5.3 & 1.528 \\
Sands & 1.557 & 5.3 & 1.516 \\
\hline
\end{tabular}


TABLE 2: Details of the triaxial data.

\begin{tabular}{|c|c|c|c|c|c|c|}
\hline $\begin{array}{l}\text { Test } \\
\text { name }\end{array}$ & $G_{s}$ & $\begin{array}{l}\text { Shearing } \\
\text { types }\end{array}$ & $\begin{array}{l}\text { Initial specific } \\
\text { volume: } v_{0}\end{array}$ & $\begin{array}{l}\text { Mean stress for shearing: } p^{\prime} \\
(\mathrm{kPa})\end{array}$ & $\begin{array}{c}\text { Final specific volume: } \\
v_{f}\end{array}$ & $\begin{array}{l}\text { Final deviatoric stress: } q_{f} \\
\qquad(\mathrm{kPa})\end{array}$ \\
\hline CFA & \multirow{9}{*}{2.780} & $\mathrm{CU}$ & 4.747 & 25 & 4.737 & 5 \\
\hline CFA & & $\mathrm{CU}$ & 4.654 & 50 & 4.525 & 12 \\
\hline CFA & & $\mathrm{CU}$ & 4.448 & 100 & 4.097 & 42 \\
\hline CFA & & $\mathrm{CU}$ & 4.582 & 200 & 4.003 & 90 \\
\hline CFA & & CU & 4.276 & 300 & 3.698 & 190 \\
\hline CFA & & $\mathrm{CU}$ & 4.389 & 400 & 3.780 & 225 \\
\hline CFA & & $\mathrm{CD}$ & 3.996 & 30 & 3.880 & 97 \\
\hline CFA & & $\mathrm{CD}$ & 4.151 & 40 & 3.940 & 81 \\
\hline CFA & & $\mathrm{CD}$ & 4.052 & 200 & 3.517 & 28 \\
\hline $\begin{array}{l}25 \% \\
\text { sands }\end{array}$ & \multirow{5}{*}{2.745} & $\mathrm{CU}$ & 2.921 & 100 & 2.808 & 33 \\
\hline $\begin{array}{l}25 \% \\
\text { sands }\end{array}$ & & $\mathrm{CU}$ & 2.912 & 300 & 2.575 & 132 \\
\hline $\begin{array}{l}25 \% \\
\text { sands }\end{array}$ & & $\mathrm{CD}$ & 2.916 & 40 & 2.740 & 93 \\
\hline $\begin{array}{l}25 \% \\
\text { sands }\end{array}$ & & $\mathrm{CD}$ & 3.076 & 200 & 2.722 & 425 \\
\hline $\begin{array}{l}25 \% \\
\text { sands }\end{array}$ & & $\mathrm{CD}$ & 3.219 & 600 & 2.390 & 1184 \\
\hline $\begin{array}{l}50 \% \\
\text { sands }\end{array}$ & \multirow{6}{*}{2.700} & $\mathrm{CU}$ & 2.712 & 100 & 2.544 & 35 \\
\hline $\begin{array}{l}50 \% \\
\text { sands }\end{array}$ & & $\mathrm{CU}$ & 2.565 & 200 & 2.409 & 89 \\
\hline $\begin{array}{l}50 \% \\
\text { sands }\end{array}$ & & $\mathrm{CU}$ & 2.725 & 500 & 2.421 & 256 \\
\hline $\begin{array}{l}50 \% \\
\text { sands }\end{array}$ & & $\mathrm{CU}$ & 2.719 & 600 & 2.408 & 346 \\
\hline $\begin{array}{l}50 \% \\
\text { sands }\end{array}$ & & $\mathrm{CD}$ & 2.569 & 300 & 2.152 & 702 \\
\hline $\begin{array}{l}50 \% \\
\text { sands }\end{array}$ & & $\mathrm{CD}$ & 2.500 & 1100 & 2.032 & 2083 \\
\hline $\begin{array}{l}80 \% \\
\text { sands }\end{array}$ & \multirow{8}{*}{2.665} & $\mathrm{CU}$ & 1.709 & 100 & 1.700 & 645 \\
\hline $\begin{array}{l}80 \% \\
\text { sands }\end{array}$ & & $\mathrm{CU}$ & 1.695 & 200 & 1.680 & 1180 \\
\hline $\begin{array}{l}80 \% \\
\text { sands }\end{array}$ & & $\mathrm{CU}$ & 1.690 & 600 & 1.666 & 2103 \\
\hline $\begin{array}{l}80 \% \\
\text { sands }\end{array}$ & & $\mathrm{CD}$ & 1.822 & 30 & 1.806 & 68 \\
\hline $\begin{array}{l}80 \% \\
\text { sands }\end{array}$ & & $\mathrm{CD}$ & 1.752 & 100 & 1.780 & 222 \\
\hline $\begin{array}{l}80 \% \\
\text { sands }\end{array}$ & & $\mathrm{CD}$ & 1.742 & 200 & 1.771 & 450 \\
\hline $\begin{array}{l}80 \% \\
\text { sands }\end{array}$ & & $\mathrm{CD}$ & 1.731 & 300 & 1.787 & 735 \\
\hline $\begin{array}{l}80 \% \\
\text { sands }\end{array}$ & & $\mathrm{CD}$ & 2.014 & 1100 & 1.674 & 2248 \\
\hline Sands & \multirow{9}{*}{2.640} & $\mathrm{CU}$ & 1.678 & 50 & 1.675 & 1039 \\
\hline Sands & & $\mathrm{CU}$ & 1.721 & 100 & 1.711 & 1188 \\
\hline Sands & & $\mathrm{CU}$ & 1.786 & 300 & 1.756 & 961 \\
\hline Sands & & $\mathrm{CU}$ & 1.686 & 70 & 1.679 & 1452 \\
\hline Sands & & $\mathrm{CU}$ & 1.713 & 140 & 1.698 & 1382 \\
\hline Sands & & $\mathrm{CU}$ & 1.712 & 300 & 1.690 & 1896 \\
\hline Sands & & $\mathrm{CD}$ & 1.904 & 30 & 1.879 & 65 \\
\hline Sands & & $\mathrm{CD}$ & 1.684 & 200 & 1.706 & 461 \\
\hline Sands & & $\mathrm{CD}$ & 1.715 & 600 & 1.735 & 1339 \\
\hline
\end{tabular}

Note. The test name, for example sands and CFA, indicates that the sample was purely aeolian fine sands and purely coal fly ash; $20 \%$ Sands means that the sample is a mixture of $20 \%$ Sands and $80 \%$ CFA in mass. 


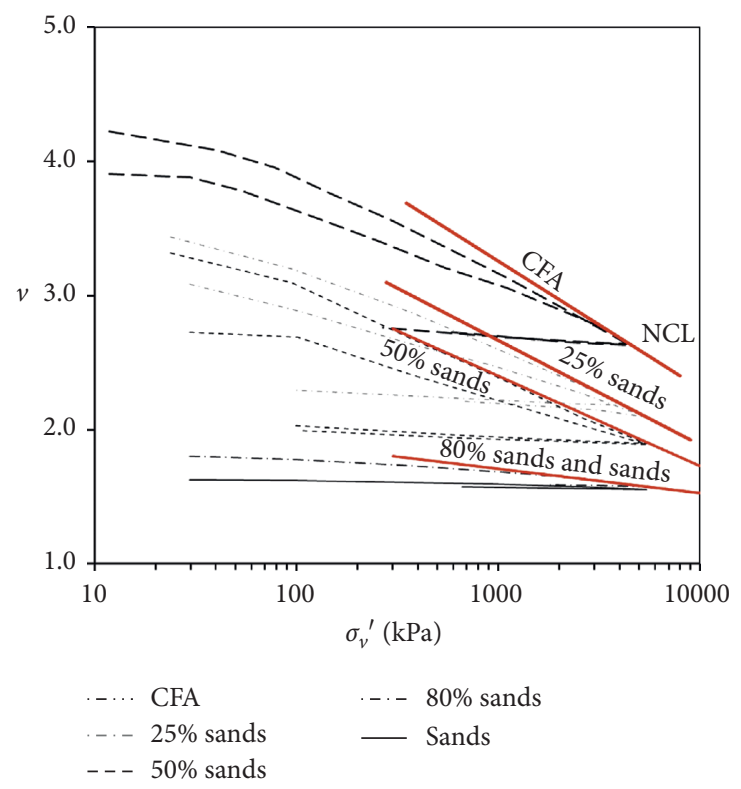

(a)

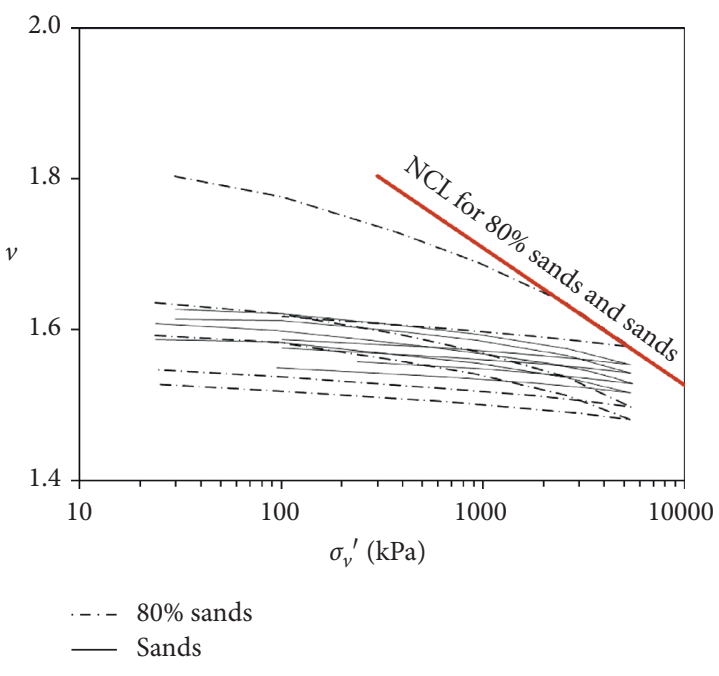

(b)

Figure 4: Oedometer test results of (a) all samples and (b) detailed curves of $80 \%$ sands mixtures and pure sands.

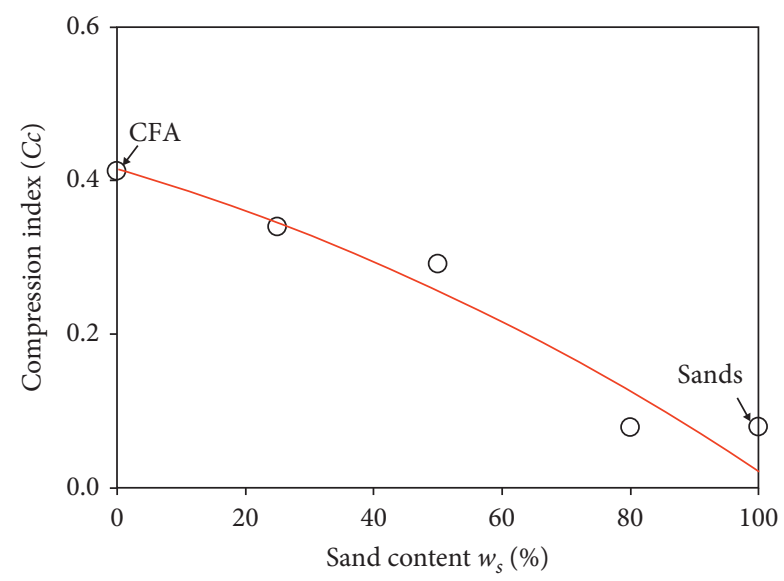

Figure 5: Compression index $C_{c}$ versus sands contents.

contrary, the $80 \%$ sands and pure sands exhibit a transient contractive behaviour followed by a total dilatancy (see Figure 7(b)).

3.3. Stress-Dilatancy Results. The stress-dilatancy results during drained triaxial tests are presented in Figure 8. The stress-strain data are represented by a stress ratio normalized by $M, q / M_{p}^{\prime}$ to eliminate the influence of stress ratio at critical states. With the absences of elastic shear and bulk moduli, the total strains are plotted with the shear strain being calculated as $\varepsilon_{s}=\varepsilon_{v}-\varepsilon_{a} / 3$, which is assumed to be isotropy. A slightly arcshaped linear relationship can be observed between the normalized stress ratio and the total strain increment ratio in the region of large strains. The effects of sands on the dilatancystress relationships of CFA are very small. The differences among tests might be caused by the sample densities and confining stress levels.
3.4. Critical State of Tested Materials. The shearing paths of tested materials in $p^{\prime}-q$ and $v$ - $\ln p^{\prime}$ planes are shown in Figures 9 and 10, respectively. All the samples reached their critical state lines (CSL) at the end of the tests. The critical state parameters are summarized in Table 3. For CFA, 25\% sands, and 50\% sands, the stress paths of tested samples exhibit a clearly strain-softening, even though some of them show a dilatancy at the end of tests (see Figure 9). However, $80 \%$ sands or pure sands show a total dilatancy behaviour, even though some loose samples present an initial transient strain-softening. Critical state lines (CSL) in $p^{\prime}-q$ plane are also identified. $M$ values are $1.25,1.30,1.33,1.38$, and 1.49 for CFA, $25 \%$ sands, $50 \%$ sands, $80 \%$ sands, and pure sands, respectively. Correspondingly, the shearing resistance angles at critical state $\varnothing_{c s}$ are $31.1^{\circ}, 32.3^{\circ}, 33.0^{\circ}, 34.4^{\circ}$ and $36.6^{\circ}$, calculated with the following equation: $\sin \varnothing_{c s}=3 M /(6+M)$. The lower 


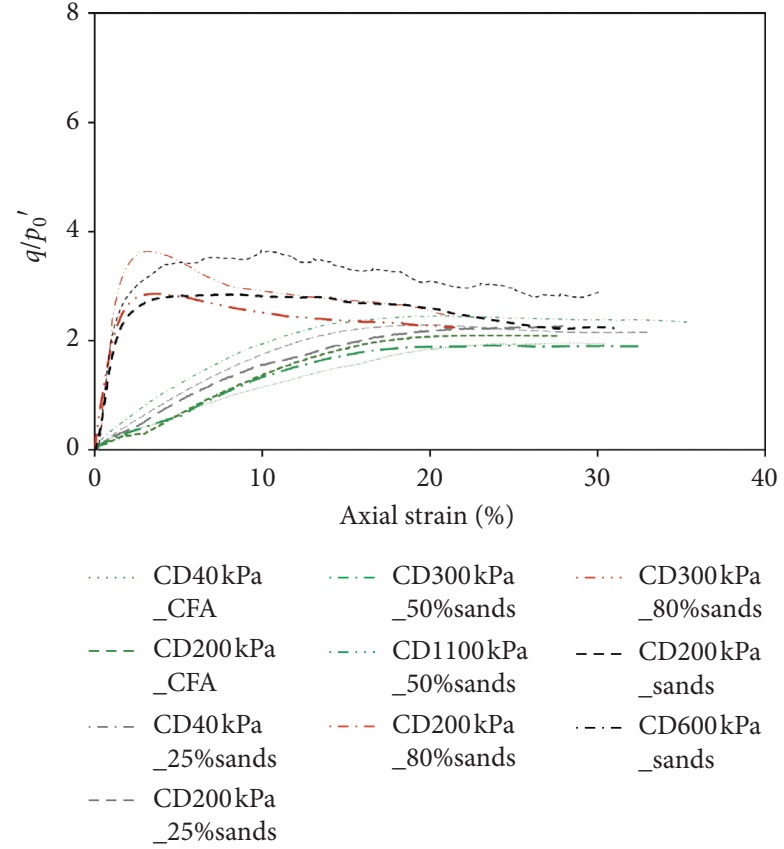

(a)

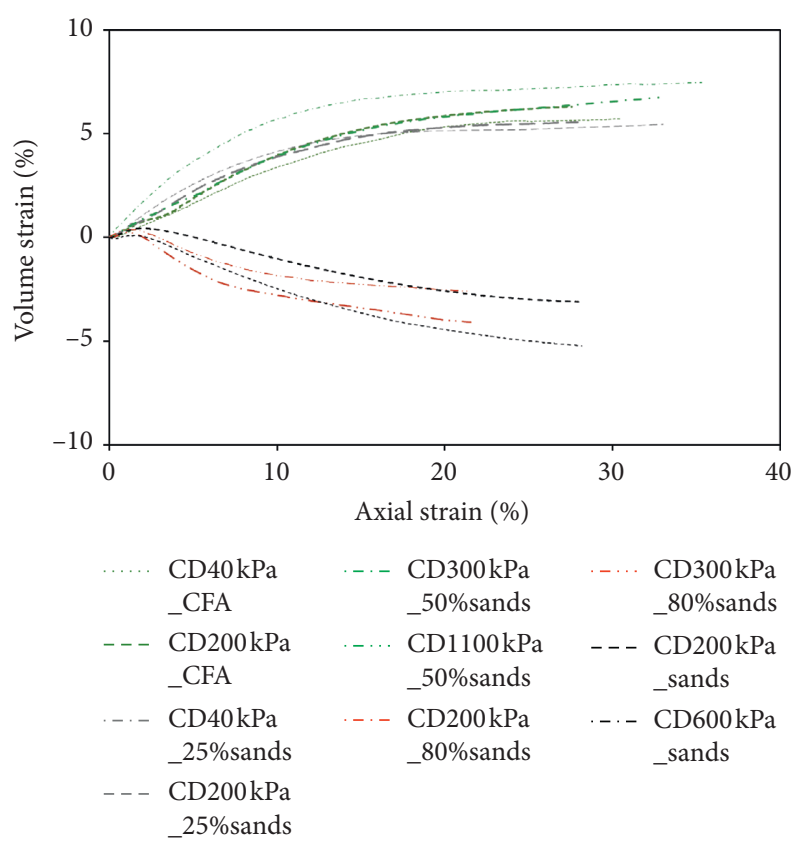

(b)

Figure 6: Typical triaxial test data. (a) Normalized deviator stress by initial confining effective stress-axial strain curves. (b) Volume changes for drained tests. Note. $q=\sigma_{1}^{\prime}-\sigma_{3}^{\prime} ; p_{0}^{\prime}=p^{\prime}$ at the start of shearing.

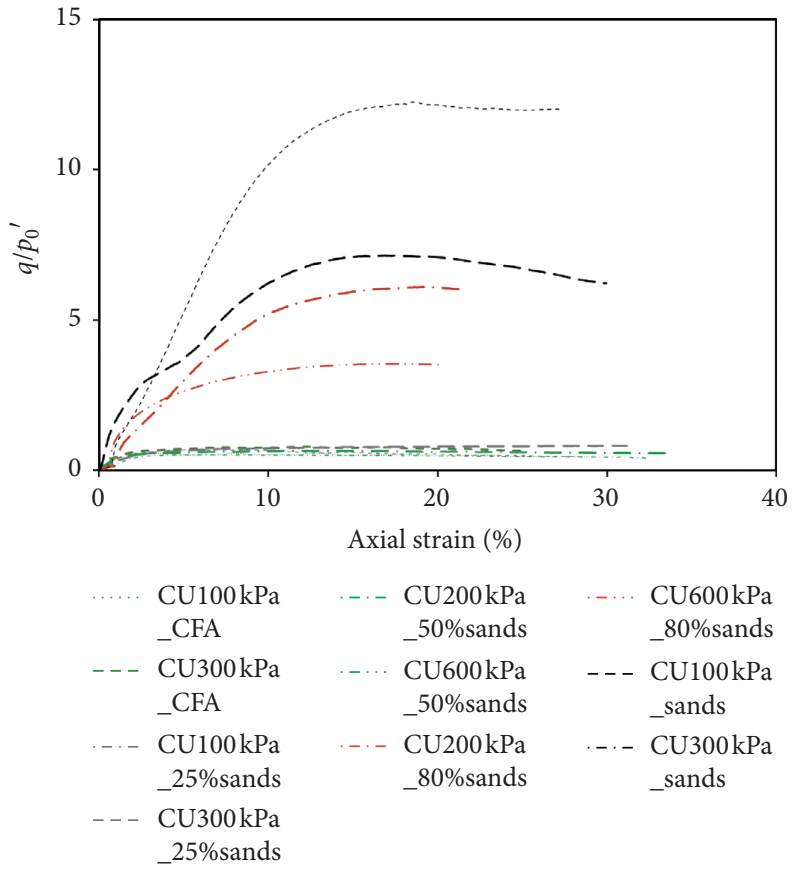

(a)

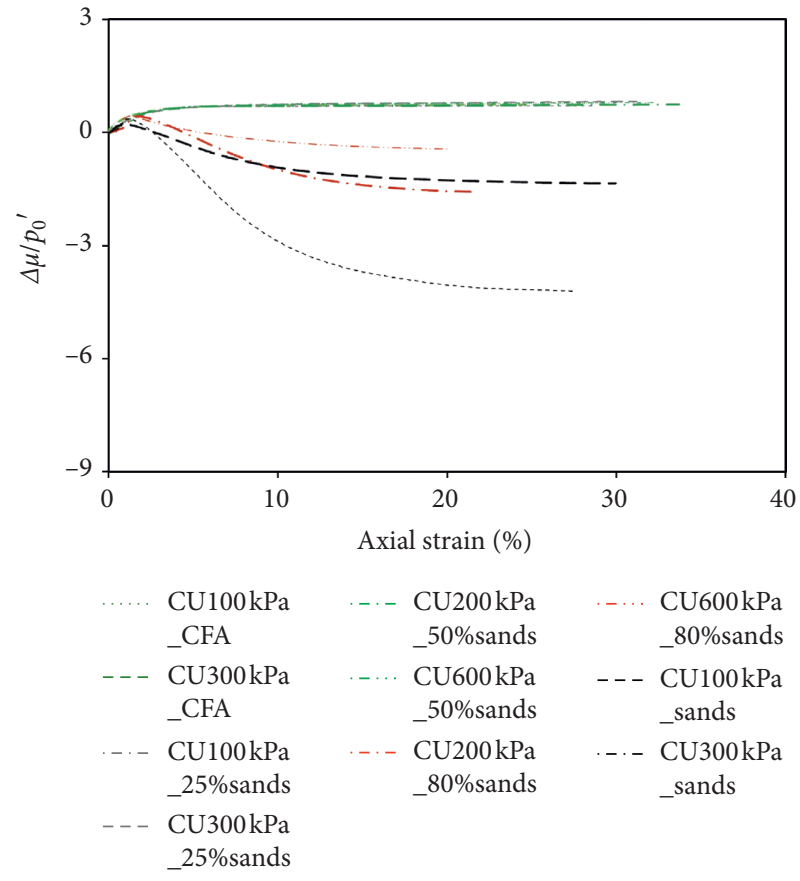

(b)

Figure 7: Typical triaxial test data. (a) Normalized deviator stress by initial confining effective stress-axial strain curves. (b) Normalized pore pressure generation for undrained tests. Note. $q)=\sigma_{1}^{\prime}-\sigma_{3}^{\prime} ; p_{0}^{\prime}=p^{\prime}$ at the start of shearing.

$M$ of CFA might be due to the more rounded shape of particles in the samples (see Figure 3(a)).

The critical states of all samples in $v$ - $\ln p^{\prime}$ plane are shown in Figure 10. CSL are identified for each sample. The
CSLs for $80 \%$ sands and pure sands are the same because their critical state points completely overlapped. It can be seen that the sands have a significant influence on the critical states of the CFA. The CSL of CFA is the highest and steepest 

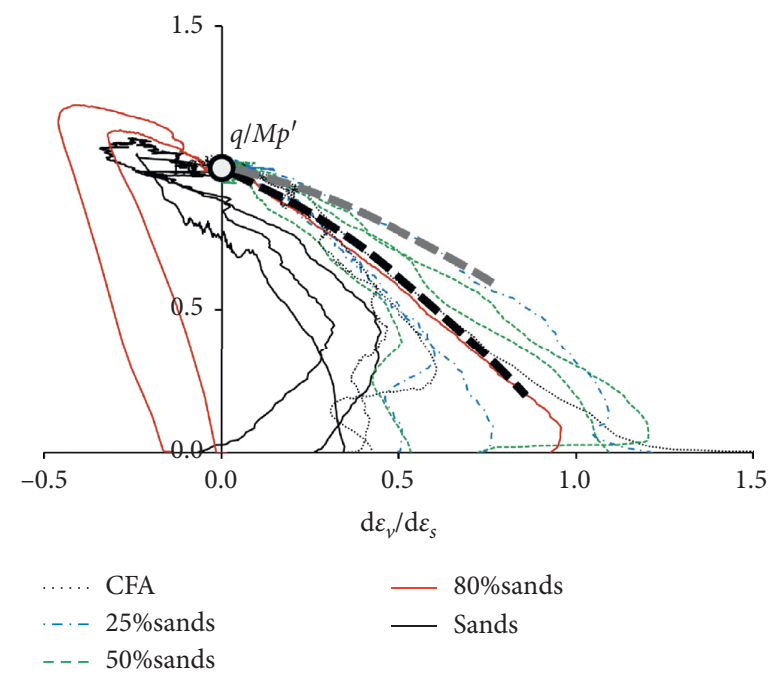

FIgURE 8: Stress-dilatancy behaviour for the drained triaxial tests.

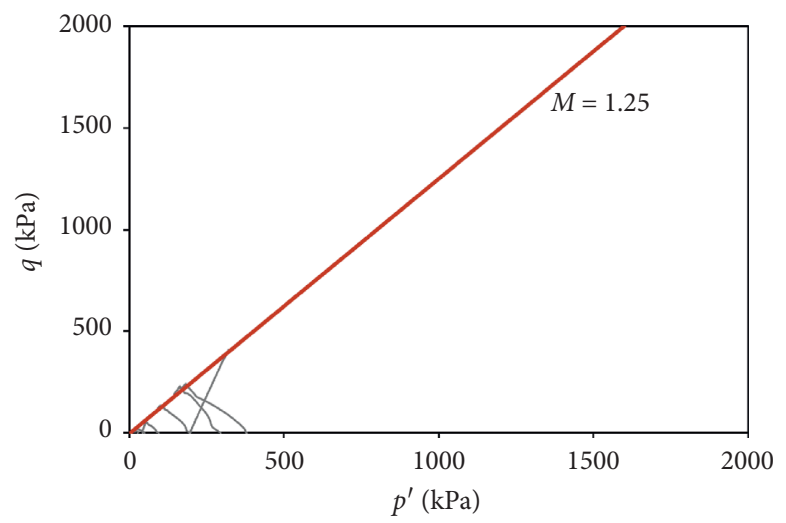

(a)

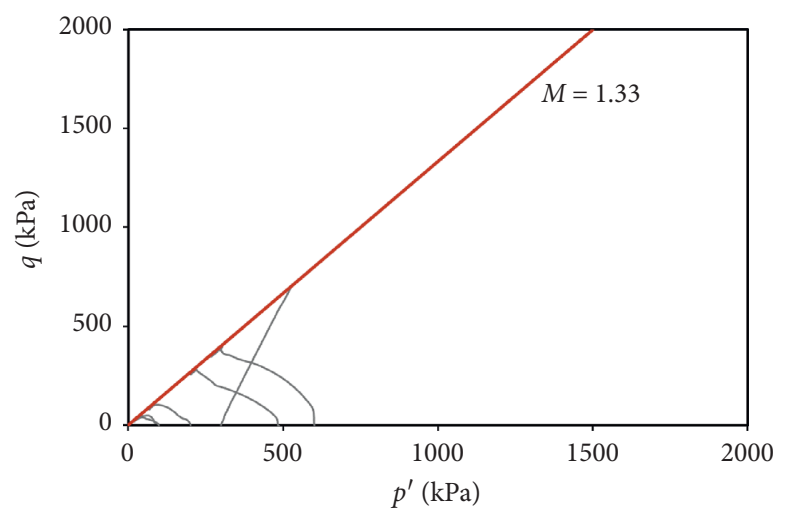

(c)

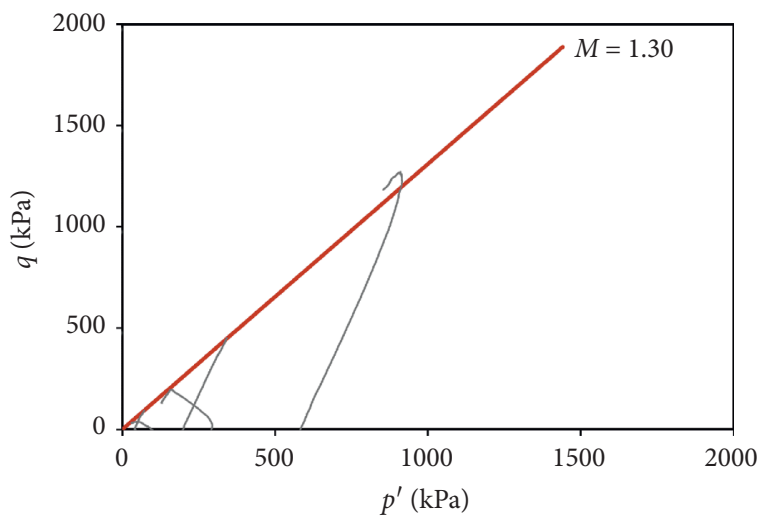

(b)

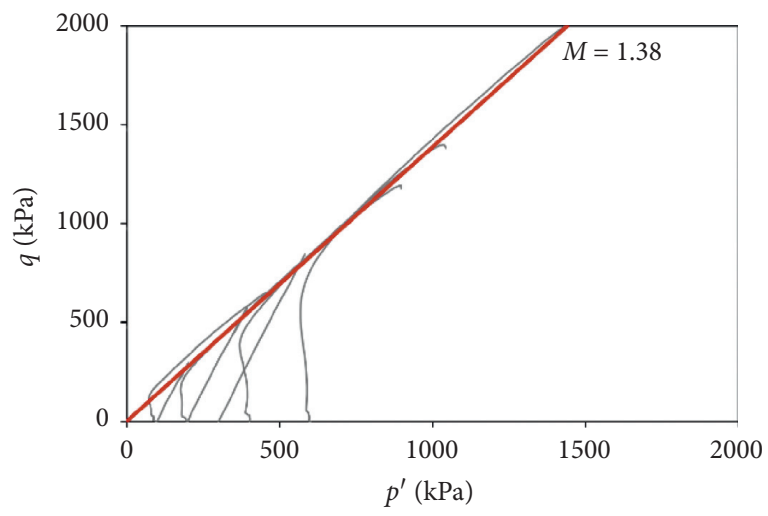

(d)

FIgURE 9: Continued. 


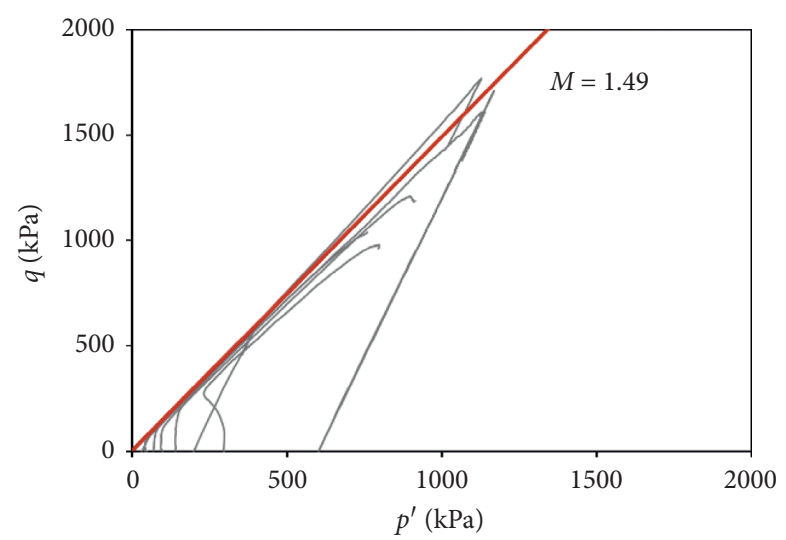

(e)

FIgURE 9: Stress paths for tested samples. (a) Pure CFA. (b) 25\% sands. (c) $50 \%$ sands. (d) $80 \%$ sands. (e) Pure aeolian sands.

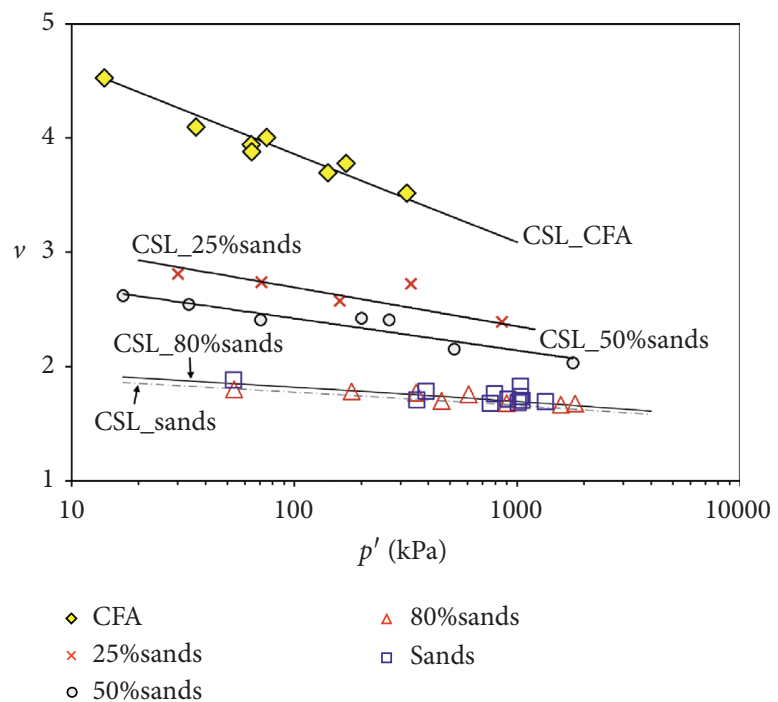

Figure 10: Critical states lines of pure CFA, $25 \%$ sands, $50 \%$ sands, $80 \%$ sands, and pure sands in the volumetric plane.

TABLE 3: Critical state parameters $\lambda, \Gamma, M$ and friction angles $\varnothing_{c s}^{\prime}$ for the tested materials.

\begin{tabular}{lcccc}
\hline Material & $\Lambda$ & $\Gamma$ & $M$ & $\varnothing_{c s}^{\prime}:\left(^{\circ}\right)$ \\
\hline CFA & 0.336 & 5.400 & 1.25 & 31.1 \\
$25 \%$ sands & 0.148 & 3.373 & 1.30 & 32.3 \\
$50 \%$ sands & 0.122 & 2.982 & 1.33 & 33.0 \\
$80 \%$ sands & 0.055 & 2.07 & 1.38 & 34.4 \\
Sands & 0.055 & 2.07 & 1.49 & 36.6 \\
\hline
\end{tabular}

in $v$ - $\ln p^{\prime}$ plane. With increasing sands content, the CSLs of CFA shift downwards and spin anticlockwise. The parameters of CSL in $v$ - $\ln p^{\prime}$ plane, i.e., $\lambda$ and $\Gamma$, were calculated as illustrated in Table 3 and Figure 10. The $\lambda$ for CFA, 25\% sands, $50 \%$ sands, $80 \%$ sands, and pure sands are 0.336 , $0.148,0.122,0.055$, and 0.055 , respectively. In addition, their $\Gamma$ values are $5.4,3.373,2.982,2.07$, and 2.07 . The test results reveal that the sands have significant effect on mechanical properties of CFA.

The parameters of $M, \varnothing_{c s}^{\prime}, \lambda$ and $\Gamma$ versus the sands content in CFA are illustrated in Figure 11. $M$ and $\varnothing_{c s}^{\prime}$ both increase with the augmenting content of sands (see Figure 11(a)). It is demonstrated that the sands can improve the shear strength of the CFA. The critical state parameters, $\lambda$ 


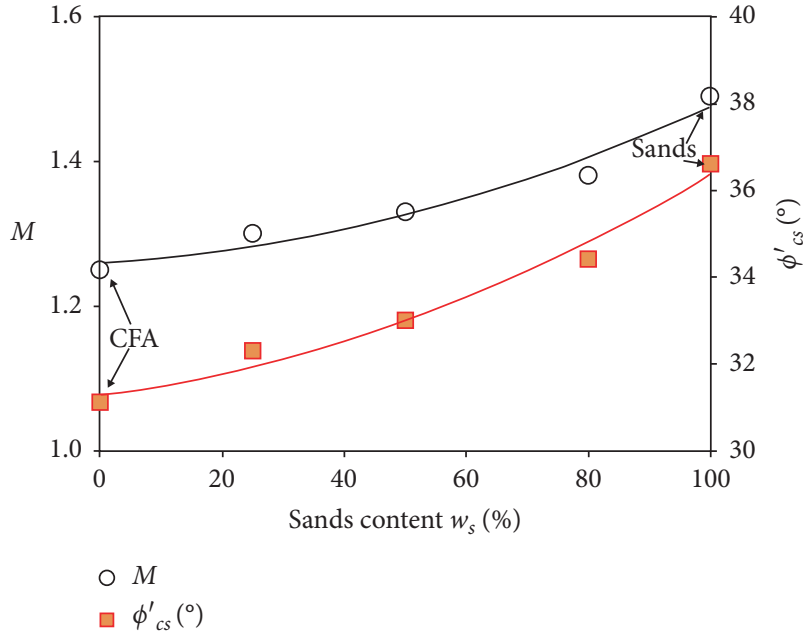

(a)

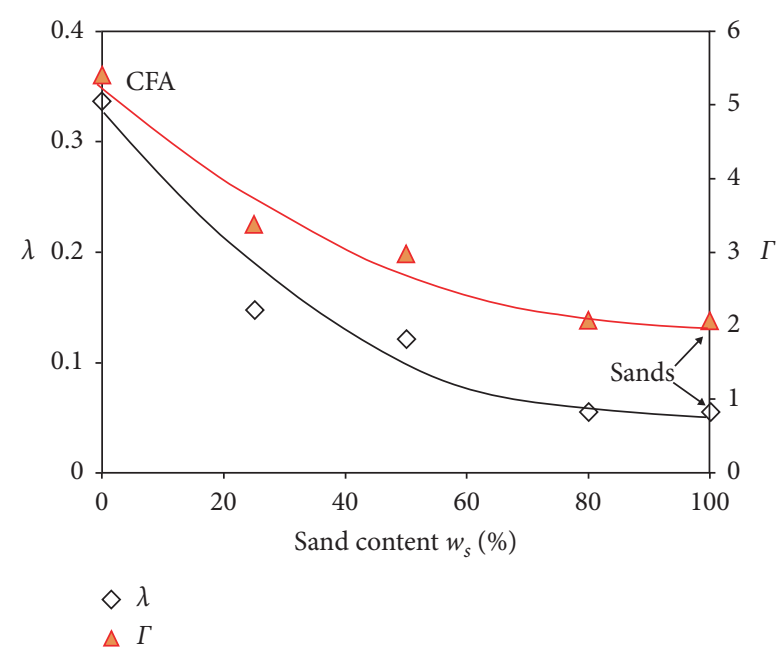

(b)

FIgURE 11: The influence of sands content on critical state parameters of $M, \varnothing_{c s}, \lambda$, and $\Gamma$.

and $\Gamma$, decrease with the increasing sands contents (see Figure 11(b)). The decreased $\lambda$ shows that the volume of mixtures is not easily changed during shearing. This is mainly because the specific volume is very small in the mixtures with higher sands content.

The triaxial results demonstrate the influence of sands on CFA in the aspect of mechanical properties, which are important for the CFA-related geotechnical and environmental applications in the northern Shaanxi province of China.

\section{Conclusions}

By carrying out a series of oedometer and triaxial tests, this study investigates the mechanical properties of pure coal fly ash (CFA), pure aeolian fine sands, and their mixtures containing $20 \%, 50 \%$, and $75 \%$ of sands by weight. The effects of sands on CFA have been investigated within the framework of critical state of soil mechanics. Test results reveal that the sands can change the locations of NCLs and CSLs in volume space as well as their compression or shearing paths before reaching NCL or CSL. The relationships between the sands contents and soil parameters $C_{c}, \Gamma$, $\lambda, M$ and $\varnothing_{c s}$ have been analyzed. The parameters $C_{c}, \Gamma, \lambda$ decrease as a result of increasing sands content. On the contrary, $M$ and $\varnothing_{c s}^{\prime}$ increase with augmenting sands content. The effect of sands on CFA is not linear with the increasing sands content, which slightly depends on their proportion. Considering the influence on the mechanical properties of the soil, the parameters of $\lambda$ and $M$ affect the liquefaction potential energy and the shear strength of the samples, which have greater impacts on the mechanical behaviours of samples.

It is indicated that the aeolian fine sands significantly influence the mechanical properties of mixtures with CFA. They decrease the compressibility and increase the shear strength of the mixtures. With more attention on ecological environment protection, the treatment and disposition of wasting residual are highly demanded for mining resources. Randomly staking or simply burying CFA can cause serious pollution. Many land-creating projects are being carried out in Northwestern China, which aims to produce more land use for city development. Herein, land fill might be a possibility for disposing such huge amount of CFA. The mixtures of aeolian sands and CFA can be considered as the filling materials in the geotechnical applications like construction of embankments for road or railway applications, etc. On one aspect, the huge amount of CFA can be disposed in this filling project; on another aspect, the newly created land can be used for agricultural production and construction, solving the land-shortage problem.

\section{Data Availability}

The data used to support the findings of this study are included within the article.

\section{Conflicts of Interest}

The authors declare that there are no conflicts of interest regarding the publication of this paper.

\section{Acknowledgments}

Special thanks should be given to Prof. Matthew Coop from University College London for his suggestions to improve the manuscript. This work was supported by the National Key Research and Development Program of China (no. 2018YFC1504700), Natural Science Foundation of China funded project (no. 41790441), and the China Postdoctoral Science Foundation (project no. 2017M623180).

\section{References}

[1] F. Ma, G. Y. Gao, X. P. Meng et al., "New technology for recycling and utilization of coal gasification waste residue," Engineering Technology, vol. 9, p. 199, 2016, in Chinese with English abstract. 
[2] S. A. Aiban, "A study of sand stabilization in eastern Saudi Arabia," Engineering Geology, vol. 38, no. 1-2, pp. 65-79, 1994.

[3] G. P. Padmakumar, K. Srinivas, K. V. Uday et al., "Characterization of aeolian sands from Indian desert," Engineering Geology, vol. 139-140, pp. 38-49, 2012.

[4] S. Abel, A. Peters, S. Trinks et al., "Impact of biochar and hydrochar addition on water retention and water repellency of sandy soil," Geoderma, vol. 202-203, no. 2, pp. 183-191, 2013.

[5] M. G. M. Elip and S. Lopez-Querol, "Aeolian sands: characterization, options of improvement and possible employment in construction - the State-of-the-art," Construction and Building Materials, vol. 73, pp. 728-739, 2014.

[6] P. Li, H. Qian, and J. Wu, "Environment: accelerate research on land creation," Nature, vol. 510, no. 7503, pp. 29-31, 2014.

[7] S. Lopez-Qerol, J. Arias-Trujillo, M. GM-Elipe et al., "Improvement of the bearing capacity of confined and unconfined cement-stabilized aeolian sand," Construction and Building Materials, vol. 153, pp. 374-384, 2017.

[8] B. Tarawneh, J. Nusairat, and Y. Hakam, "Load testing and settlement of shallow foundation on desert sands," Proceedings of the Institution of Civil Engineers - Geotechnical Engineering, vol. 171, no. 1, pp. 52-63, 2018.

[9] A. B. Fourie, G. E. Blight, and G. Papageorgiou, "Static liquefaction as a possible explanation for the Merriespruit tailings dam failure," Canadian Geotechnical Journal, vol. 38, no. 4, pp. 707-719, 2001.

[10] M. T. Zandarín, A. Luciano, A. Oldecop et al., "The role of capillary water in the stability of tailing dams," Engineering Geology, vol. 105, no. 1-2, pp. 108-118, 2009.

[11] S. Okusa, S. Anma, H. Maikuma et al., "Slope failures and debris flow characteristics during the 1984 naganoken-seibu earthquake," Journal of the Japan Society of Engineering Geology, vol. 27, no. 3, pp. 128-140, 2010.

[12] A. Carrera, M. R. Coop, and R. Lancellotta, "Nfluence of grading on the mechanical behavior of Stava tailings," Géotechnique, vol. 61, no. 11, pp. 935-946, 2011.

[13] N. Chang, G. Heymann, and C. Clayton, "The effect of fabric on the behaviour of gold tailings," Géotechnique, vol. 61, no. 3, pp. 187-197, 2011.

[14] J. Bedin, F. Schnaid, A. V. D. Fonseca et al., "Gold tailings liquefaction under critical state soil mechanics," Géotechnique, vol. 62, no. 3, pp. 263-267, 2015.

[15] A. T. Özer and L. G. Bromwell, "Stability assessment of an earth dam on silt/clay tailings foundation: a case study," Engineering Geology, vol. 151, pp. 89-99, 2012.

[16] F. Schnaid, J. Bedin, A. J. P. Viana Da Fonseca, and L. De Moura Costa Filho, "Stiffness and strength governing the static liquefaction of tailings," Journal of Geotechnical and Geoenvironmental Engineering, vol. 139, no. 12, pp. 21362144, 2013.

[17] Q. Zhang, G. Yin, Z. Wei, X. Fan, W. Wang, and W. Nie, “An experimental study of the mechanical features of layered structures in dam tailings from macroscopic and microscopic points of view," Engineering Geology, vol. 195, pp. 142-154, 2015.

[18] Y. Xiao, H. L. Liu, X. M. Ding et al., "Influence of particle breakage on critical stage line of rockfill material," International Journal of Geomechanics, vol. 16, no. 1, pp. 1-18, 2016.

[19] B. Nilo, C. Consoli, P. Domingos et al., "Behavior of compacted soil-fly ash-carbide lime mixtures," Journal of Geotechnical and Geoenvironmental Engineering ASCE, vol. 127, no. 40, pp. 774-782, 2001.

[20] N. C. Consoli, A. D. Rosa, and R. B. Saldanha, "Variables governing strength of compacted soil-fly ash-lime mixtures,"
Journal of Materials in Civil Engineering, vol. 23, no. 4, pp. 432-440, 2011.

[21] N. C. Consoli, C. Gravina, and S. Maghous, "Strategies for developing more sustainable dosages for soil - coal fly ash - lime blends," Journal of Materials in Civil Engineering, vol. 28, no. 11, pp. 1-8, 2016.

[22] N. C. Consoli, T. M. De Paula, M. S. Bortolotto et al., "Coal fly ash-carbide lime admixtures as an alternative to concrete masonry blocks: influence of ash grounds," Journal of $\mathrm{Ma}$ terials in Civil Engineering, vol. 29, no. 2, pp. 1-6, 2017.

[23] A. Carrera, M. Coop, and R. Lancellotta, "Influence of grading on the mechanical behaviour of Stava tailings," Géotechnique, vol. 61, no. 11, pp. 935-946, 2011.

[24] C. P. Polito and J. R. Martin II, "Effects of nonplastic fines on the liquefaction resistance of sands," Journal of Geotechnical and Geoenvironmental Engineering, vol. 127, no. 5, pp. 408415, 2001.

[25] A. Sadrekarimi, "Influence of fines content on liquefied strength of silty sands," Soil Dynamics and Earthquake Engineering, vol. 55, pp. 108-119, 2013.

[26] L. Zuo and B. Baudet, "Determination of the transitional fines content of sand-non-plastic fines mixtures," Soils and Foundations, vol. 55, no. 1, pp. 213-219, 2014.

[27] K. A. Kwa and D. W. Airey, "Critical state interpretation of effects of fines in silty sands," Géotechnique Letters, vol. 6, no. 1, pp. 100-105, 2016.

[28] M. G. M. Elipe and S. López-Querol, “Aeolian sands: characterization, options of improvement and possible employment in construction - the State-of-the-art," Construction and Building Materials, vol. 73, pp. 728-739, 2014.

[29] P. P. Pease, G. D. Bierly, V. P. Tchakerian, and N. W. Tindale, "Mineralogical characterization and transport pathways of dune sand using Landsat TM data, Wahiba Sand Sea, Sultanate of Oman," Geomorphology, vol. 29, no. 3-4, pp. 235-249, 1999.

[30] I. H. Khan, "Soil studies for highway construction in arid zones," Engineering Geology, vol. 19, no. 1, pp. 47-62, 1982.

[31] H. A. Al-Sanad, N. F. Ismael, and A. J. Nayfeh, "Geotechnical properties of dune sands in Kuwait," Engineering Geology, vol. 34, no. 1-2, pp. 45-52, 1993.

[32] Y. Yuan, X. Wang, and X. Zhou, "Experimental research on compaction characteristics of aeolian sand," Frontiers of Architecture and Civil Engineering in China, vol. 2, no. 4, pp. 359-365, 2008.

[33] E. S. Abu Seif, "Performance of cement mortar made with fine aggregates of dune sand, Kharga Oasis, Western Desert, Egypt: an experimental study," Jordan Journal of Civil Engineering, vol. 7, no. 3, pp. 270-284, 2013.

[34] F. M. Howari, A. Baghdady, and P. C. Goodell, "Mineralogical and gemorphological characterization of sand dunes in the eastern part of United Arab Emirates using orbital remote sensing integrated with field investigations," Geomorphology, vol. 83, no. 1-2, pp. 67-81, 2007.

[35] G. P. Padmakumar, K. Srinivas, K. V. Uday et al., "Characterization of aeolian sands from Indian desert," Engineering Geology, vol. 139-140, pp. 38-49, 2012.

[36] A. J. Al-Taie, Y. J. Al-Shakarchi, and A. A. Mohammed, "Investigation of geotechnical specifications of sand dune: a case study around Baiji in Iraq," International Journal of Advanced Research, vol. 1, no. 6, pp. 208-215, 2013.

[37] H. A. Al-Sanad and S. P. Bindra, "Soil Mechanics for Road Engineers in Arabian Peninsula, Kuwait University, Kuwait, 1984. 
[38] C. S. Dunn and M. N. Salem, "Influence of processing procedures on strength of sand stabilized with cationic bitumen emulsion", National Research Council, Washington, D.C., 1971.

[39] M. N. Fatani and H. A. Sultan, "Dune Sand-Aggregate Mixes and Dune Sand-Sulfur Mixes for Asphalt Concrete Pavement," Transportation Research Record, National Academy of Science, Washington, D.C., 1982.

[40] Y. E.-A. Mohamedzein, M. Y. Al-Aghbari, and R. A. Taha, "Stabilization of desert sands using municipal solid waste incinerator ash," Geotechnical and Geological Engineering, vol. 24, no. 6, pp. 1767-1780, 2006.

[41] N. K. Ameta, A. S. Wayal, and P. Hiranandani, "Stabilization of dune sand with ceramic tile waste as admixture," American Journal of Engineering Research, vol. 2, no. 9, pp. 133-139, 2013.

[42] Z. A. Baghdadi and M. A. Rahman, “The potential of cement kiln dust for the stabilization of dune sand in highway construction," Building and Environment, vol. 25, no. 4, pp. 285-289, 1990.

[43] B. S. Albusoda and L. A. Salem, "Stabilization of dune sand by using cement kiln dust (CKD)," Journal of Earth Science and Geotechnical Engineering, vol. 2, no. 1, pp. 131-143, 2012.

[44] J. Schwan, "The origin of horizontal alternating bedding in Weichselian aeolian sands in northwestern Europe," Sedimentary Geology, vol. 49, no. 2, pp. 73-108, 1986.

[45] ASTM, D. 3551: Standard Practice for Laboratory Preparation of Soil-Lime Mixtures Using Mechanical Mixer, ASTM International, West Conshohocken, PA, USA, 2008. 